\title{
A Case Study on the Multiplatform Strategy Used by NET in the Indonesian Television Industry
}

\author{
Firman Kurniawan Sujono ${ }^{1, *}$ Marlia Yossie ${ }^{2}$
}

\author{
${ }^{1}$ Universitas Indonesia \\ ${ }^{2}$ Universitas Indonesia \\ *Corresponding author. Email: firmankurniawan@yahoo.com
}

\begin{abstract}
A network society can easily produce, share, broadcast, capture, and record information through digital devices. The emergence of such a society has widespread implications. The traditional, one-way mass communication model is gradually becoming defunct because television media, must adopt the new media paradigm of migration from monoto multi- media. This transformation is an inevitable step for the industry in response to the. network society's methods of consuming media. The multichannel-TV industry is thus increasing its efforts to benefit from the changes in the way consumers like to view video content, even when these modifications disrupt its own traditional business model.
\end{abstract}

Keywords: Network Society, Television, New Media, Multimedia

\section{INTRODUCTION}

A network society is a social structure that characterizes what is popularly known as the information society or the post-industrial social order. The main structures and activities of a network society are organized according to electronically processed information networks. A network society processes and manages information using micro-electronic technology (Castells, 2011). In such a community, individuals are capable of producing, sharing, broadcasting, capturing, and recording information with ease through the use of digital electronic devices. As a consequence, users are able to obtain information that spreads exponentially through the network, becoming, to use a popular term, viral (Usher \& Carlson, 2018).

A network society results from the development of digital technology that seeps into every aspect of public life. This dissemination of technology creates hitherto unforeseen situations, that bring new challenges in their wake: novel relationships with audiences (interactivity), new languages (multimedia), and new grammars (hypertext). The media revolution transforms the communication landscape for ordinary players. Most importantly, it also introduces a system of mass communication to a large number of new players (Orihuela, 2003). Companies, institutions, organizations, groups, families, and individuals become content producers and are able to express their abilities to a wide audience. Their articulations, in turn, become a source of the news reported by traditional media. Often, digital content disseminated by network users also provokes criticism through the mainstream media's reporting of surrounding events. This new media, created by anyone who wants to, can also offer alternative reports to counter traditional media channels.

Orihuela has documented the formulation of new paradigms in the digital era, in which the information consumption behavior of a network society grows and develops. One such emergent paradigm is the change from monomedia to multimedia, wherein the digitization of text, audio, video, graphics, photos, and animation allows everything to be arranged together interactively within a single digital platform. The multimedia identity of this actual environment allows the productions of all media industries to be displayed online (press, broadcasting, film).

The network society's means of consuming online media has forced television stations to try to adapt, even though such an adjustment requires them to institute changes that are contrary to the television industry's traditional business model. A survey by marketing consultants Frank N. Magid Associates showed for the first time that the millennial generation, of people aged between 18 and 34 years would rather own a smartphone 
(88\%) than subscribe to cable TV (83\%). In addition, according to a statement made by Andrew Hare, the Magid research director (Winslow, 2015), 70\% of this age group subscribes to over-the-top (OTT) providers such as Netflix or Hulu Plus.

In the late 2000s, television was no longer referred to as an object one would watch. Instead, the meaning of the word began to refer to content to be streamed, downloaded, and shared. Tens of millions of viewers have "cut the cord" or performed "cord cutting," i.e., they have replaced cable television with online services such as Netflix, Hulu, and YouTube. They also view pirated films and programs with unexpected speed. Therefore, the idea that the Internet will one day destroy the television industry and the film industry in the same way as it destroyed the music industry no longer seems far-fetched (Strangelove, 2015).

In Indonesia, the television industry is facing the emergence of Internet-based digital media such as online media and social media which offer product substitution opportunities. The Indonesian Internet User Penetration and Behavior Survey was conducted by the Indonesian Internet Service Providers Association (APJII) in 2019. From the demand aspect, the results of this survey, evince a significant growth in Internet usage in Indonesia: from 143.26 million in 2017 to 171.17 million in 2018. This aggregate figure pertaining to Internet users corresponded to $64.8 \%$ of Indonesia's total population of 264.16 million in 2018. The data further reveal that the percentage growth of Internet users in 2017-2018 was $10.12 \%$, far ahead of the $0.63 \%$ growth in population in that same period. According to user behavior profiles, 93.9\% of Internet users in Indonesia access the Internet every day through smartphones, with entertainment content in the form of movies or videos being the most frequently consumed content, by $45.3 \%$ of the users. We Are Social released a report on the time spent on digital media by the Indonesian population in 2019. According to this report, the average daily time spent using the Internet on any device was 8 hours 36 minutes, while the average daily time spent using social media on any device was computed as 3 hours 26 minutes. Both these figures are far higher than the average daily TV viewing time (broadcast, streaming, and video on demand), which was only 2 hours 52 minutes.

With a growing understanding of the new way in which people consume their information, free to air television stations began using a multiplatform approach to product distribution. As a result, television content can be accessed both using a broadcasting frequency and through the Internet. Live streaming and video on demand for television content can now be enjoyed on various social networking sites like Facebook and YouTube, while some stations even have OTT services that allow their viewers to enjoy the channel's products through digital media. One example is the multiplatform strategy used by NET. At the time of its birth in 2013, NET. became a television pioneer, allowing all of its content, both live streaming and video on demand, to be accessed through its YouTube channel. NET. also incorporates several digital platforms operating under new media paradigms that are aligned with Orihuela's postulations. At that time, NET. appeared with the tagline Televisi Masa Kini.

NET. premiered on May 18, 2013. Besides YouTube, numerous NET. broadcasts can be streamed via Facebook, as well as through its VoD service. Additionally, NET. is also available on the Zulu digital platform, an OTT service through which audiences can watch both live streaming and VoD NET. shows anytime and anywhere. A user generated content-based platform was also developed and named NETCJ. The audience can upload and share original video content generated by viewers as Citizen Journalists. However, in 2019, NET. abandoned its digital multiplatform strategy under growing business pressures. Consequently, some steps were taken to rescue NET., including employees being laid off and a realignment of the company to focus exclusively on free to air broadcasts (Warta Ekonomi Online, 2019). The NET tagline was also changed to Nonton TV Asiknya di NET., a campaign that invited viewers to watch NET. content on television. The original multiplatform strategy that initially shaped the NET. identity was stripped off.

The overview of what is happening in NET. can be seen from a media economic perspective as reflective of the current circumstances of the media industry. With reference to Albarran (1996), media economics may be defined as a discipline that specializes in the manner in which the media industry manages its scarce resources to produce content that is distributed among its consumer community and that corresponds to the wants and needs of this community. In practice, the study of media economics applies three reciprocal analytical frameworks: market conduct, market structure, and market performance. Such an analysis is essentially centered on an explanation of how a business unit that belongs to the media industry arranges its market conduct as a response to certain market structures and produces market performance that can eventually affect the market structure again.

This paper describes an investigation conducted on the basis of the analysis framework of the media economics perspective of the television market structure faced by NET., evoking the market conduct of the multiplatform strategy of distributing content. This paper also elucidates how the internal policies of NET., devised through its market conduct and external market conditions, influenced the media organization's business performance so that in the end, NET. was compelled to again change its strategy. 


\section{METHOD}

This study used the descriptive analytic approach, which reports empirical data and then analyzes its theoretical relevance. In this study, the principles of the new paradigm of media in the digital age were used as a foothold from which to observe and describe the steps taken by NET. as a television industry entity when it implemented its multiplatform strategy. Broadly speaking, the problem faced by NET. was dissected through the perspective of the market structure-market conduct-market performance analysis framework of industrial organization theory. For the purposes of this research, interviews were conducted with the Vice President of the Technical and Innovation division that handles the development of the NET. digital platform, the Business Director, and the Vice President of Corporate Finance at NET. Supporting data have also been used from surveys and from the findings of previously conducted research to strengthen the analysis conducted for the present study.

\section{RESULT}

\subsection{Market Structure}

The massive use of microelectronics in the digital era serves as a context for NET. and for its business mode of catering to a society that demands new media, new grammar, and new language for the dissemination of its desired information. The multimedia packaging of information is thus the most suitable form for such a society. Given this reality, the multiplatform strategy adopted by NET. was aimed at complementing its television business. Notably, this strategy was also a departure from the structure of the television market that existed when NET. was first established.

Prior to the emergence of NET. in 2012, the free to air television industry was characterized by the dominance of three market players (the big three), both in terms of the audience and the advertising markets: the Global group Mediacom which manages RCTI, Global TV, MNC TV, and Inews; the Elang Mahkota Teknologi group directing SCTV and Indosiar; and the Trans Media Group that owns Trans TV and Trans 7. The big three controlled $83.1 \%$ of the audience share, and $80.9 \%$ of the share of advertising revenue in 2012. Unsurprisingly, the dominance of these three media groups created industrial market entry barriers and formed less competitive patterns that tended to be oligopolistic (Nainggolan, 2018).

However, Nielsen's data (2017) evidences that threequarters of the total media industry advertising market is still absorbed by national television, which consists only of 15 television business operators. In fact, in 2012, before the emergence of NET., RTV, and Kompas TV, this advertising revenue cake was only divided among 12
TV businesses. In 2011, an estimated Rp 44.06 trillion in advertising spending was absorbed into the television industry. This number rose even further in the following year, to Rp 53.7 trillion (Nainggolan, 2018).

NET., with its vision to become a dominant content provider, emerged in this backdrop, and chose television as its main channel, hoping to capture a large share of advertising revenue. In order to differentiate itself from existing television stations and to strengthen its own competitiveness in terms of acquiring audiences and advertising revenue, NET. also adopted multiplatform strategies for product distribution. The purpose of adopting such a strategy was to attract the younger generation or the "millennials" who were accustomed to consuming content in a manner peculiar to a network society. Therefore, NET. was not just chasing television viewers; it also aimed to entice those who viewed content through secondary screens such as smartphones, tablets, or laptops. Up until NET.'s arrival, the preferences of these viewers had not been sufficiently explored by conventional television.

"We have seen that in the future the way
people consume content, the way people
enjoy the media will be different. At that time
there was no first screen second screen
discussion. So, when we were on the market
nobody talked about it and saw that, we
launched it."
(Business Director, NET. Personal interview
on August 16, 2019.)

In that time, NET.'s slogan was Televisi Masa Kini. NET. identified itself as a monomedia operator and represented the old media communication model. However, the brand also stepped into the realm of multimedia through digital platforms such as Zulu and NETCJ, and through the utilization of a social media platform for streaming and distributing VoD content. On its multiplatform channel, NET. adopted a new media paradigm where multimedia became its language used and the user became the backbone of the communication process.

\subsection{Market Conduct}

Although it operated in multiplatform broadcasting, from the industry side NET. considers the investment required to become a serious new media platform capable of adapting to the culture of a network society to pose its own challenges. The returns on capital investments become risky, uneven, and uncertain because the industry has not fully matured. YouTube and Facebook are still considered to be the top choice of advertisers. A top management functionary asserted:

"Regarding technology, there are two things, the availability of technology itself 
and the ability of talent. Unlike the terrestrial TV industry, this new mediaspecific technology is not yet widely available. The ability of talent to be able to think of new media including platforms and other supporting technologies is also still minimal.

Investing to become a serious new media platform has its challenges because the immature industry makes investment vs. return unbalanced and in reality today, our two distant brothers YouTube and Facebook are still the main choices of advertisers

The business model choice is crucial, because there is no credible research about the choice between subscription based or advertising-based models or even a combination between both being the right choice, especially for the Indonesian market."

(Vice President of Technical and Innovation NET. Personal Interview on May 24, 2019.)

According to Digital Compendium data released by the Boston Consulting Group (BCG) in March 2019, YouTube and Facebook each controlled 28 percent of the Advertising-based VoD (AVoD) market in 2018. (see figure 1)

Indonesia market is highly driven by global player AVOD \& telco-affiliated SVOD

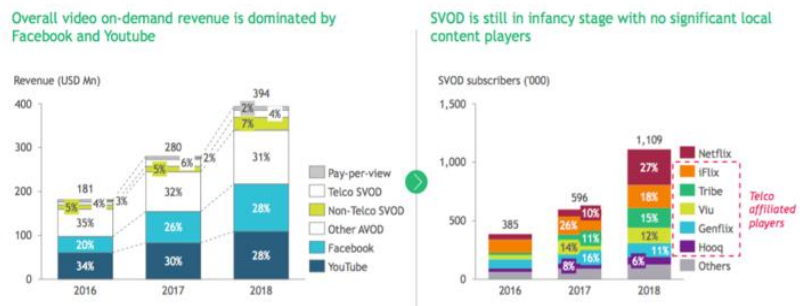

Figure 1 YouTube and Facebook domination in AVoD market Indonesia (Source: Digital Compendium BCG, 2019).

The Vice President said that current online multimedia that are often accessed by network society audiences appear promising, but there is also a proliferation of new media players, and individuals are also becoming media publishers. The vagaries of supply and demand can make prices go down again. This volatility is juxtaposed against terrestrial TV, which requires high investment, is highly regulated, and has channel limitations. (Vice President of Technical and Innovation NET., Personal Interview, May 24, 2019)

This consideration is why television was adopted as the main infrastructure of NET., both in terms of engineering and in the provision of resources. NET. digital products are essentially television products that are partially distributed directly through digital platforms, while some content is to better suit the preferences of online audiences.

The choice of television as NET.'s main business means that its management falls within the purview of the tv company umbrella, including the administration of its indigenous digital multiplatform. Zulu as an OTT service; its social media and the development of its other digital products are carried out in coordination with the engineering and innovation division, while NETCJ and the NET.Z online news portal are under the news division. The purpose of this organizational structure, in which content was produced under one large television umbrella, was to make to make the process of content production more efficient. This configuration also served to sustain the original vision of NET. as a contentproducing entity whose products could be distributed anywhere:

"NET. strategy TV is the main platform. But what we emphasize is that we have DNA called creative content. Content creation. Because TV is actually just a platform. Right in the future, the distribution of content that we will develop is not only on TV, but also on mobile phones and all kinds. TV is the backbone, our license is on TV."

(Vice President of Corporate Finance NET. Personal Interview on August 16, 2019.)

\subsection{Market Performance}

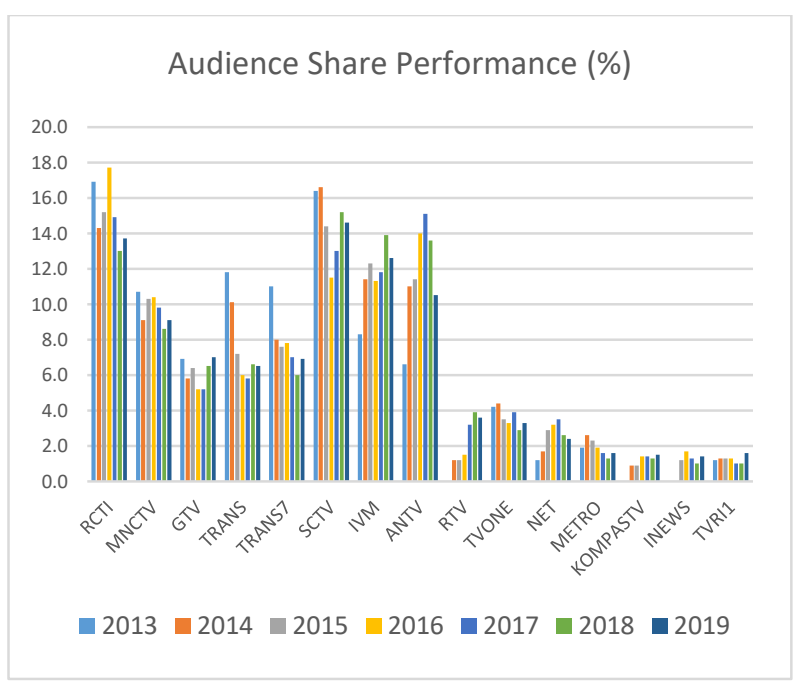

Figure 2 Audience Share Performance Television Stations in Indonesia (Source: Nielsen Media 20132019).

The performance of a television station can be measured by two parameters: audience share 
performance and share of advertisement revenue. In operating a multiplatform strategy according to conduct suited to the television industry, NET's audience share performance touched the bottom layer of national television stations (see figure 2). Meanwhile, NET.'s earnings in terms of advertisement revenue could not recover its production costs. Unsurprisingly, after six years of broadcasting, NET. was still incurring losses in 2018: NET. issued a production cost of around 800 billion rupiahs a year, while its income was only in the range of 600 billion rupiahs (Vice President of Corporate Finance NET., Personal Interview, August 16, 2019)

This situation was very unfavorable for NET. because its audience share performance was still the dominant measure used by advertisers to determine their allocation of advertising budgets to a television station. A small audience share brings little in terms of advertisements, and this was rather problematic for NET. whose main income was dependent on television advertising.

In the digital realm, where YouTube and Facebook are still the most widely used platforms in Indonesia (We Are Social, 2019), the position of NET. lags far behind. Data collected by socialblade.com on YouTube video viewers demonstrate that "Ini Talkshow," a NET. program, is ranked 9th below the RCTI-Layar Drama Indonesia, Indosiar, TRANS7 official, TRANS TV official, MNC TV official, cumi-cumi, Surya Citra Televisi (SCTV) and NAGASWARA official videoIndonesia Music. While the Netmediatama channel station itself is ranked 11. Based on the number of subscribers, NET. ranks $42^{\text {nd }}$, while based on SB rank, NET. occupies the 59th position with Grade A-. For readers who are unaware, SB Rank is a rating system that measures a channel's influence based on a variety of metrics, including average view counts and the number of "other channel" widgets in which it is listed. Channels that have an $\mathrm{A}+, \mathrm{A}$, or A- SB rank are considered to be very influential on YouTube (socialblade, 2019).

For Facebook performance in Indonesia, data from socialbaker.com indicates that the NET. Facebook page does not appear among the top 20 pages with the most fans. The Facebook page owned by NET. only appears in the top 10 media pages. Its total number of followers trail far behind those for Kompas.com, which is the top media page on Facebook in Indonesia (see figure 4). (socialbaker, 2019)
Facebook Stats Indonesia

(Total Fans)

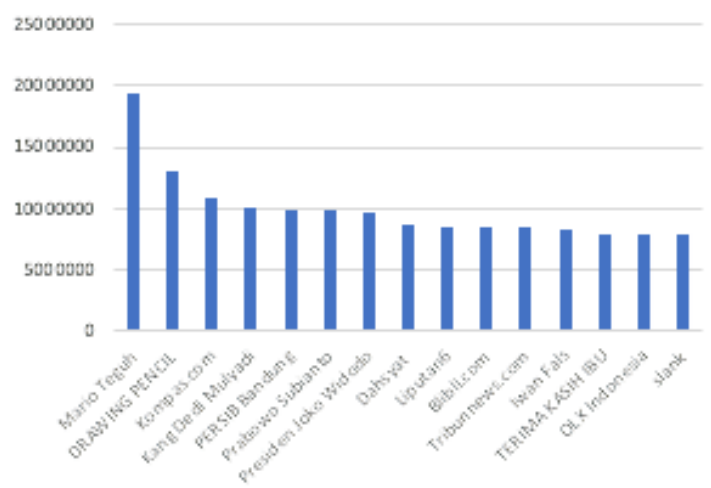

Figure 3 Facebook Page Stats 2019 (source: socialbaker.com)

Facebook Stats Media in Indonesia (Total Fans)

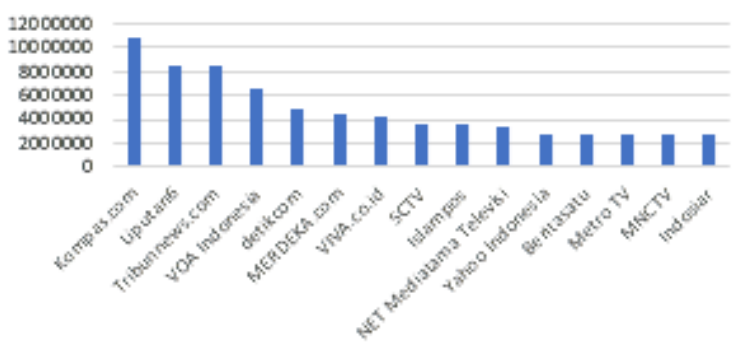

Figure 4 Facebook Stats - Media in Indonesia 2019 (source: socialbaker.com).

Digital multimedia invites the participation of an abundance of publishers. Therefore, media entities must also deal with individual entities, groups, companies, and even social movements to attract the attention of diverse audiences. Thus, the competition has become even tougher than the type of rivalry that characterized conventional television broadcasters.

\section{DISCUSSION}

In practice, the operational merger of two media paradigms under one large umbrella creates a number of obstacles for television organizations. NET., which was built on television infrastructure, with most of its resources coming from the television industry, faced the problems accruing from a lack of expertise and supporting technology to create a flourishing digital media environment. 
Combining the production of digital content and free to air television under one roof also complicates production cost calculations, essentially because content for television is fundamentally discrete from content for digital platforms. Cost, marketing, and sales strategy calculations must be adjusted to each targeted market because the audience for the television market is distinguished from the viewers that form the digital market. NET. produced its content at the cost of its television programming. The results of the production were free to air broadcasts, but they were also channeled directly or with slight adjustments to digital channels, both on social media and on OTT platforms. The cost of the digitally available product is thus difficult to evaluate because of the overlapping expenses and interrelating target markets. This lack of clarity exerted an impact on the rates set by NET. for its digital products. (Business Director NET., Personal Interview, August 16, 2019).

NET.'s lack of focus in the production and allotment of its content on both television and as multiplatform digital content is acknowledged by its management. Due to the consequent fallouts, NET. started to separate its digital arm from its television operations. Unfortunately, this step was forced on NET. when it was experiencing financial difficulties. (Vice President of Corporate Finance NET., Personal Interview, August 16, 2019).

The main target audience of NET. comprise millennials who represent a network society evincing the characteristics of consuming significant amounts of information via the Internet. The increasing use of digital media creates the assumption that this new technology dominates over conventional media. Contrary to this assumption, every target audience uses a combination of media on a day-to-day basis. A study released by Nielsen Media in 2018 provides some interesting insights. Although $58 \%$ of millennial groups (20-34 year olds) and $50 \%$ of Generation Z (10-19 year olds) access the Internet, more than $90 \%$ of these age groups also apparently still watch television (see figure 5). Additionally, the data reveal that $90 \%$ of Gen X and Baby Boomer groups also watch television (Bachdar, 2019; databoks.katadata.co.id, 2018). This finding suggests the continued presence of a substantial number of potential television viewers in Indonesia.

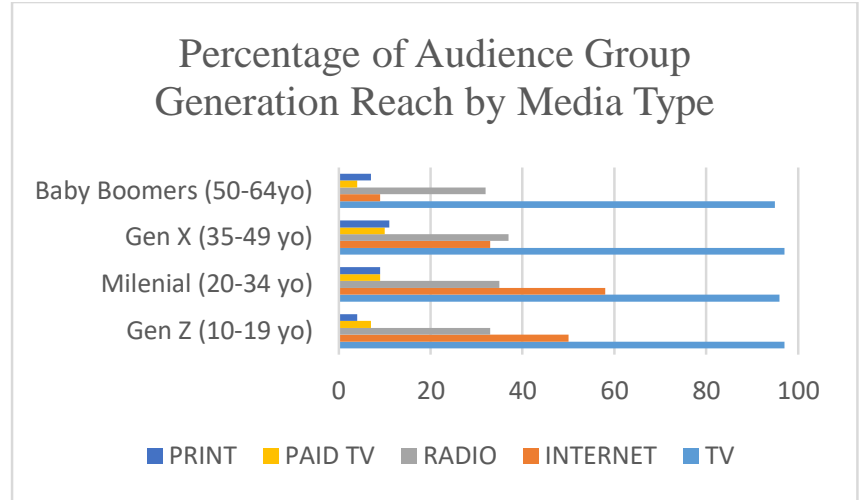

Figure 5 Percentage of Audience Group Generation Reach by Media Type (source: Nielsen Consumer Media View 2018).

In circumstances of the limited availability of capital in mid-2019, and given that television is its main income, NET. focuses on free to air broadcasting. The company's multiplatform strategies are being reevaluated by the temporary freezing of several of its digital platforms and continuing with its social media channels, which do not require much financial input. NET.'s slogan has also changed to Nonton TV Asiknya di NET., a campaign urging audiences to watch television broadcasts only on NET.

This new strategy is also selected because of the readiness of NET.'s existing television infrastructure and its vast potential to attract television advertising spending (see figure 6). (Vice President of Corporate Finance NET., Personal Interview, August 16, 2019).

Indonesian TV ADEX market is expected to grow to USD 1.4B by 2022 NET.

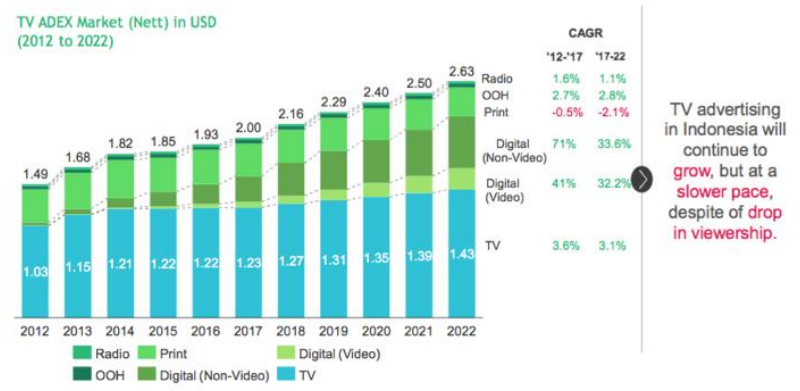

Figure 6 TV Adex Market in USD (source: Nielsen Data, DBS Analyst Report, Media Partner Asia, BCG Analysis, Convertion Rate 14000 IDR=1 USD

\section{CONCLUSION}

Even if NET. is compelled to be realistic about the situation at hand, building digital platforms with multimedia features is still a target for the company's future media business. Capital will be collected from the ongoing television operations, but the company's conduct 
as it approaches the multiplatform market in the future will be far different from its previous foray. It should be noted that companies operating on multiple platforms must be ready to face individual players with personal accounts who can live with micro valued advertisements. Ideally, a distinct organizational identity should be evolved for the company to enter the new context of the television business in the era of network society.

The atmosphere of uncertainty surrounding the survival of players in the free to air television channel industry or of their expanding their reach to multimedia mandates emphasis on a crucial point. According to the industry players interviewed for this study, video viewing will continue to survive and the trend is guaranteed to increase. However, the platforms and the consumption patterns are likely to change. Every media has its own individual audience characteristics and requires business houses to adopt the right strategy to hook the attention of these audiences. Meanwhile, TV will also continue to exist as long as there are advertisers and as long as all audiences do not shift to mobile platforms.

Regardless of whether video viewing survives through monomedia or through multimedia, the power of content remains the focus. How the content can attract attention, adjust with technology, and how it is different from erstwhile offerings are major concerns in this area. There is no doubt that superior content sustains the success of most media products: previous studies explaining the adoption of technology related to video or entertainment services have illustrated the impact of content. Competitive content was the main reason why television replaced radio when it was introduced to the market. Subsequently, radio repositioned itself as a niche media to distinguish itself from television (Lin, 2009).

Through its attempt to migrate online, NET. highlighted the importance of the use of artificial intelligence for multimedia television. Its effort to understand the interests of its audiences, to ensure that its content was channeled to the right device, and to engage its viewers may have been ill-timed, but it was still commendable. In the end, the platform or publisher will still sell eyeballs for each generated content (Vice President of Technical and Innovation NET., Personal Interview, May 24, 2019).

\section{REFERENCES}

[1] Albarran, A. B. (1996). Media economics: Understanding markets, industries and concepts ( $\mathrm{p}$. 53). Ames, IA: Iowa State University Press.

[2] APJII (2019). Hasil Survei Penetrasi dan Perilaku Pengguna Internet Indonesia 2018. Retrieved from https://apjii.or.id/survei

[3] Bachdar, S. (2018, February 15). Jangan Heran, 97\% Generasi Z Masih Menonton Televisi.
Retrieved from http://marketeers.com/janganheran-97-generasi-z-masih-menonton-televisi/

[4] Castells, M. (2011). The rise of the network society, 12. Chichester: John Wiley \& Sons.

[5] Cha, J., \& Chan-Olmsted, S. M. (2012). Cha and Chan-Olmsted, "relative advantages of online video platforms and television according to content, technology, and cost-related attributes." First Monday, 17(10). doi: 10.5210/fm.v17i10.4049

[6] Kim, D. (2018). Age of media convergence. Media Governance in Korea, 1980-2017, 111-131. doi: 10.1007/978-3-319-70302-2_9

[7] Lin, C. A. (2009). Mass communication and society audience attributes, media supplementation, and likely online service adoption, (June 2014), 37-41. doi: 10.1207/S15327825MCS0401_03

[8] Media Digital Membunuh Media Konvensional? (n.d.). Retrieved from https://databoks.katadata.co.id/datapublish/2018/02/ 18/media-digital-membunuh-media-konvensional.

[9] Nainggolan, B. (2018). DINAMIKA KONSENTRASI PASAR INDUSTRI PERTELEVISIAN NASIONAL. Jurnal Aspikom, 3(4), 767-782. doi: 10.24329/aspikom.v3i4.242.

[10] Orihuela, J. L. (2003, June). eCommunication: The 10 paradigms of media in the digital age. In IIA2O COST conference

[11] Socialbakers. (n.d.).Most popular Facebook pages in Indonesia. Retrieved from https://www.socialbakers.com/statistics/facebook/p ages/total/indonesia/page-1-2.

[12] Strangelove, M. (2015). Post-TV: Piracy, CordCutting, and the Future of television. University of Toronto press. Retrieved from https://books.google.co.id/books?id=JR_IBwAAQ BAJ\&dq=strangelove + posttv\&lr $=\&$ hl $=\mathrm{id} \&$ source $=$ gbs_navlinks_s

[13] Top 250 Youtubers in Indonesia (n.d.). Retrieved from https:/socialblade.com/youtube/top/country/id YOUTUBERS IN, Indonesia, 250.

[14] Usher, N., \& Carlson, M. (2018). The midlife crisis of the network society. Media and Communication, 6(4), 107-110.

[15] Winslow, G. (2015). Racing toward television's future. Multichannel news, 36, 12-13. Retrieved from https://search.proquest.com/docview/1643154991?a countid $=17242$ 